薛自 求 ${ }^{1}$ 石島 洋 二 ${ }^{2}$ 高 橋 学 ${ }^{3}$

\title{
Permeability and Microgeometry of Sandstones Under Hydrostatic Pressure
}

by Ziqiu XUE ${ }^{1}$, Yoji ISHIJIMA ${ }^{1}$ and Manabu TAKAHASHI ${ }^{2}$

1. Faculty of Engineering, Hokkaido University, Kita-ku, Sapporo 060

2. Environmental Geology Department, Geological Survey of Japan

The microgeometry or texture of a porous medium determines the physical properties, e.g., the transport and acoustical properties of sedimentary rock. In order to better understand the relation between microgeometry and permeability, samples of two sandstones (Shirahama and Kimachi) were submitted to hydrostatic pressure cycles while pore pressure was kept constant.

For loading, the permeability decreased obviously at the low pressure level, and decreased slightly when the pressure increasing. For unloading, the permeability was little altered by the pressure change, contrary to the loading condition. Cycling the hydrostatic pressure caused nonrecoverable changes (hysteresis) in permeability, volumetric strain and velocity (P-wave and S-wave).

A series of blue dye expoxy-impregnated thin sections of the two sandstones was prepared from the stressed and unstressed samples. Using an image analyzer the porosity of Shirahama sandstone decreased from $6.54 \%$ to $4.86 \%$ after stressed to $49 \mathrm{MPa}$. Closure of pores caused the hysteresis in permeability, volumetric strain and velocity of Shirahama sandstone. Instead of pore closure, compaction of clastic caused the large hysteresis in volumetric strain of Kimachi sandstone. It is clear that these characteristics of the permeability have a close relation with the microgeometry.

KEY WORDS: Permeability, Volumetric Strain, Velocity, Hydrostatic Pressure, Hysteresis, Pore

\section{1. はじめに}

岩石の透水係数は, 静水王, 差応力, 間隙水王などが作用する と影響を受けることはすでに詳しく調べられている ${ }^{1) 〜 3) 。 し か も ， ~}$ 透水係数はこれらの压力の一義的な関数になっていないことが明 らかになっている。つまり，圧力を繰り返し負荷させると，載荷 過程と除荷過程では, 透水係数の值が異なり, ヒスデリシスが生 じる ${ }^{4)}$ 。

これらの透水特性は, 岩石内部に分布する空隙の微視的構造, 特に, 間隙水の通路となりうるポアやクラックから構成されるネ ットワークと密接に関係している ${ }^{5) 6)}$ 。本研究では, 偏平な微小亀 裂をクラック，それ以外の空隙をポフと呼ぶことにする。これら

1992 年 4 月 10 日受付 7 月 3 日受理 資源・素材学会平成 4 年度 春季大会にて一部発表

. 学生会員 北海道大学大学院 工学部資源開発工学科

2. 正会員 工博 北海道大学教授 工学部資源開発工学科

3. 正会員 工博 工業技術院地質調查所環境地質部 主任研究員

キーワード : 透水係数, 体積ひずみ, 弾性波速度, 静水圧, ヒステリシ ス,ポフ
のポアやクラックの形状，大きさおよびその分布形態は，岩石を 構成している鉱物粒子の種類や粒径などに影響され, 岩種によっ てかなり異っている7) 岩種によって透水特性が異なる。

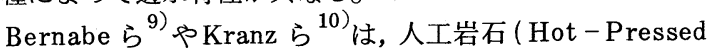

Calcite ) とジョイントを含んだ花崗岩について, 静水圧の繰り 返し負荷に伴う透水係数のヒステリシスを調べ, その原因が塑性 流動の発生やジョイント内の間隙水が平衡状態に達するまでに時 間を要するためであると報告した。彼らはこの種の現象を時間効 果と呼んでいる。しかし，このような時間効果を配慮して測定し た場合にも, 透水係数のヒステリシスは認められた ${ }^{11)}$ 。Sprunt and Brace ${ }^{12)}$ やFeves and Simmons ${ }^{13)}$ は, この現象が主に岩 石の鉱物粒子同志をつなぐ架橋（ブリッジ）の破壊やポアやクラ ックの閉鎖によって起こると説明している。

これまでのこの種の研究は, 花崗岩のような結晶質の岩石に関 するものが多く, 堆積岩に関する詳細な検討はまだなされていな い。そこで, 本研究では, 空隙率の異なる 2 種類の砂岩について, その透水挙動, とりわけ, 透水係数のヒステリシスと岩石内部の 
Table 1 Mechanical and physical properties of Shirahama and Kimachi sandstones.

\begin{tabular}{llcc}
\hline Items & & Shirahama & Kimachi \\
\hline Uniaxial compressive strength $(\mathrm{MPa})$ & 60 & 31 \\
Young's modulus & $(\mathrm{GPa})$ & 9.1 & 6.1 \\
Poisson's ratio & & 0.24 & 0.23 \\
Porosity & $(\%)$ & 13 & 23 \\
Compressional wave velocity & $(\mathrm{km} / \mathrm{sec})$ & 3.06 & 2.45 \\
Shear wave velocity & $(\mathrm{km} / \mathrm{sec})$ & 2.15 & 1.61 \\
\hline
\end{tabular}

微視的構造との関係についても検討することにした。このため, 一定の間隙水王の下で, 静水王を数回繰り返し負荷するときの透 水係数と体積ひずみを測定した。また, 岩石内部のポアやクラッ クの状況を把握する一助として, 両岩石について, 透水試験と同 様な載荷経路で静水圧を負荷するときの弾性波速度（Ｐ波および S 波) の挙動を調べた。さらに, 負荷前後の岩石供試体から得た 薄片を基に, ポアやクラックの形状や分布状態を偏光顕微鏡下で 観察した。特に, 白浜砂岩については負荷前後の供試体における 空隄の変化を画像処理によって定量的に評価した。

以上の実験結果や䫒微鏡観察結果を用い，静水王下における両 岩石の透水係数, 体積ひずみ, 弾性波速度の挙動, とりわけヒス テリシスについて，岩石の微視的構造に基づき解釈した。

\section{2. 供試岩石と透水試験法}

\section{$2 \cdot 1$ 供試岩石および供試体の準備}

供試岩石として用いた和歌山県産白浜砂岩と島根県産来待砂岩 の基本的な物性值をTab le 1 に示す。堆積層理面に対する水の流 れる向きによって透水係数が異なるという報告がある ${ }^{14)}$ 。そこで, 本研究では, 堆積層理面に直交するようにコアボーリングをし, 直径 $30 \mathrm{~mm}$, 長さ $60 \mathrm{~mm}$ の円柱形を切り出し, 上下端面の平行度 を約 $1 / 100$ に仕上げた。

供試体のひずみを計測するために，合計 4 枚のクロス型抵抗線

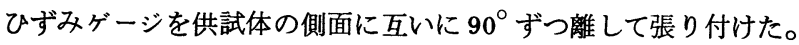
供試体の体積ひずみはこれらのゲージから得た供試体の軸方向お よび周方向のびずみ量から計算して求めた。

$1 \sim 2$ 週間続く静水圧下の透水試験の期間中, 静水匤の媒体と なる油が供試体内へ浸入するのを防ぐために，まず，粘性の低い シリコン樹脂 (信越シリコン $\mathrm{KE}-45-\mathrm{TS}$ ) を $2 \sim 3 \mathrm{~mm}$ の均一な 厚さになるまで数回に分けて塗り，それからさらに粘性の高い樹 脂（信越シリコンシーラント 45 ）を重䍿りし，供試体のコーテ ィングを入念に行った。

\section{$2 \cdot 2$ 透水試験の方法および試験装置}

透水係数はFig. 1 に示す装置を用い, Braceら ${ }^{15}$ によって提案 されたトランジェント・ハルス法によって測定した。実験方法の 詳細については高橋・薛 ${ }^{16)}$ を参照されたい。本方法は王力条件を 自由に設定することができ，定水位法や変水位法に比べて，測定 精度が高く, しかも測定時間が短いなどの利点がある。静水王の 大きさと透水係数のヒステリシスとの関係を明らかにするために， 間隙水王を一定（3MPa）にしたまま, 静水圧の大きさを第 1 ス テージ $(7 \sim 19 \mathrm{MPa})$, 第 2 ステージ $(19 \sim 37 \mathrm{MPa})$, 第 3 ステ ージ $(37 \sim 49 \mathrm{MPa})$ と 3 つのステージに分け, 第 1 , 第 2 , 第 3 ステージの順に, それぞれ 1 サイクルだけ静水王を載荷 - 除荷 させ，その間の透水係数と体積ひずみを測定した。このとき, 載 荷過程では静水匠を $3 \mathrm{MPa}$ ずつ増加させ, 除荷過程では静水王 を $6 \mathrm{MPa}$ ずつ減少させた。なお, 第 3 ステージだけは 1 サイク ルの載荷一除荷をした後, 再び $49 \mathrm{MPa}$ まで載荷し, そこで試験

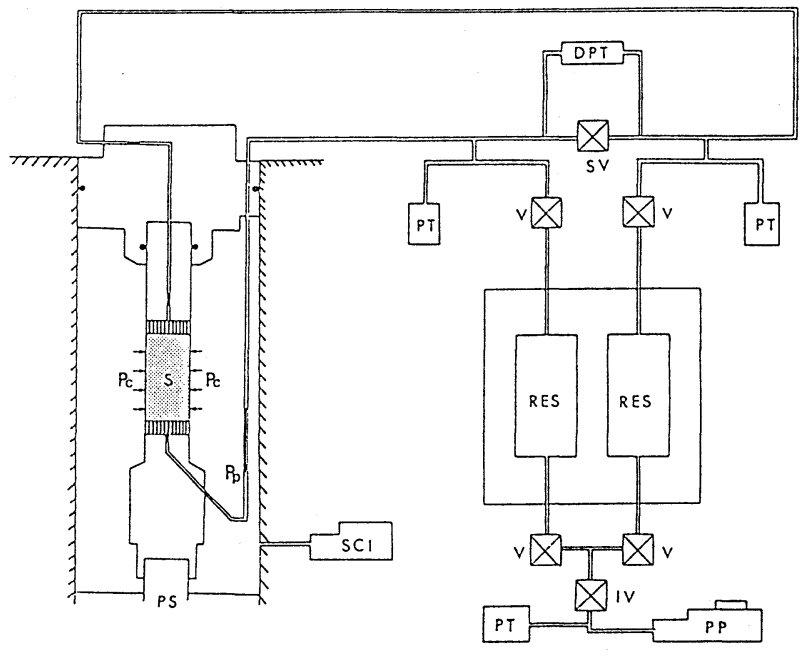

Fig. 1 Schematic drawing of the sample assembly and the permeability measurement system. $\mathrm{S}=$ Sample $\mathrm{PS}=$ Piston for Axial Loading $P_{c}=$ Confining Pressure $P_{p}=$ Pore Pressure $\mathrm{SCl}=$ Servo-Controlled Instensifier $\mathrm{PP}=$ Pore Pressure Pump $\mathrm{IV}=$ Isolation Valve $\mathrm{V}=$ Valve $\mathrm{PT}=$ Pressure Tansducer RES $=$ Reservoir $(1,000 \mathrm{cc}) \quad$ DPT $=$ Differential Pressure Transducer $\mathrm{SV}=$ Separate Valve

を終了した。 同一の間隙水王下で 1 サイクルだけ静水圧を $49 \mathrm{MPa}$ まで載荷 一除荷する試験を既に行っているが ${ }^{11 ）}$, それによると白浜砂岩, 来待砂岩の残留体積ひずみはそれぞれ $0.3 \%$ と. $7 \%$ であった。

\section{$2 \cdot 3$ 弾性波速度の測定方法}

透水試験に用いた供試体と同一のブロックから角柱 $(35 \mathrm{~mm} \times$ $35 \mathrm{~mm} \times 50 \mathrm{~mm}$ ) の供試体を作り，長軸方向に伝播する $\mathrm{P}$ 波と振動 方向が直交する二つの $\mathrm{S}$ 波の速度を測定するために, 計 3 組の王 電素子を両端面にはりつけた。王電素子 ( P Z T ) の共振周波数は $\mathrm{P}$ 波が $1 \mathrm{MHz}, \mathrm{S}$ 波が $0.5 \mathrm{MHz}$ である。弾性波速度はパルス透過 法を用いて測定した。弾性波の初動到達時間を測定するために, 透過波と発振パルスをトランジェントメモリに記録した。トラン ジェントメモリのA/D変換は分解能 10 ビット, サンプリングタイ ムは20nsecである。なお,これらの実験においては，供試岩石を 乾燥状態とし, 透水試験と同様な載荷経路で静水王を負荷したと きの弾性波速度（P波および $\mathrm{S}$ 波）を測定した。

\section{$2 \cdot 4$ 岩石の微視的構造の観察について}

岩石に含まれているポアやクラックの形状, 大きさ, 分布状態 を調べるために, 種々の手法が考案されている。例えば, 走査型 電子顕微鏡や偏光顕微鏡を用いた直接的な観察法がある。この他 に，樹脂を供試体に王入するポアキャスト法 ${ }^{17)}$ や弾性波速度を用 いたインバージョン法 ${ }^{18)}$ がある。

薄片を用いた偏光顕躴鏡観察においては, ポアやクラックの識 別が容易にできるように, 薄片製作時に青色顔料を添加した樹脂 をポアやクラックに充填する方法がよく用いられる。Ehrlich $ら^{19)}$ は, このような手法による観察結果を基に, 王力の負荷に伴 う岩石の透水係数の変化と, 負荷前後のポアの大きさや分布の変 化との間に関連が認められると報告している。

本研究では薄片を用いた顕微鏡観察法を採用した。この方法は 従来から細長い亀裂や幅が $1 \mu \mathrm{m}$ 以下のクラックの観察には適し ていないと指摘されている ${ }^{20 ）}$ 。しかし,手摺りを中心とした研磨に より薄片の厚さを $50 \mu \mathrm{m}$ 前後に仕上げ, 阿部 ${ }^{21)}$ と同様に着色樹脂 をポアやクラックに充填する方法を用いることにより, 細長い亀 裂が観察できるようになった。Fig・2 は粒界や粒内を貫通する 


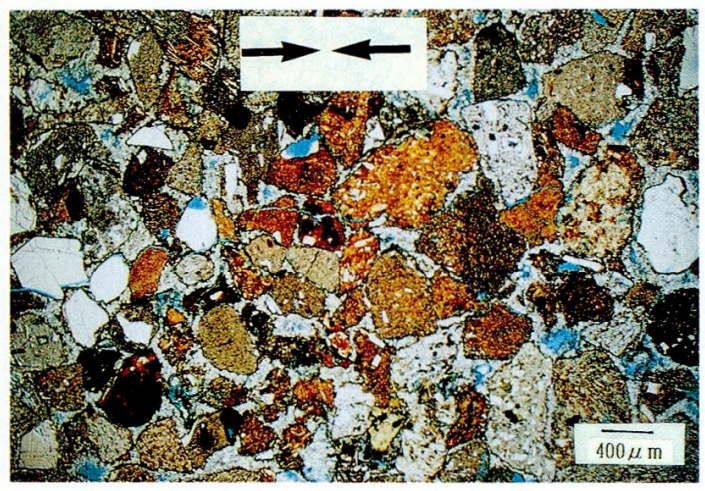

Fig. 2 Optical photomicrograph of Kimachi sandstone from triaxial compression test (after Xue et al. 21) )

The fracture has formed around or across grains. The arrows show the direction of the maximum compression.

約 $20 \mu \mathrm{m}$ 程度の開口幅をもつ亀裂の様子を明瞭に観察でき た例を示している。また,大きさ $20 \mu \mathrm{m}$ 程度のポアやクラッ クの観察が可能となった。これに関する詳細は薛ほか ${ }^{22)}$ 参照されたい。

\section{3. 透水試験および弾性波速度試験の結果}

\section{$3 \cdot 1$ 透水係数に及ぼす静水圧の影譥}

透水係数はFig.3に示すように, 静水圧の増加に伴って減少す るが, 静水圧の負荷のステージが進むにつれ，透水係数の減少の 程度が小さくなり，第 3 ステージではほとんど減少しなくなる。 このため, 透水係数一静水圧線図は下に凸の形になっている。こ れらの挙動は両岩種に共通している。ただし, 静水圧の増加に伴 う透水係数の減少の程度は白浜砂岩の方が来待砂岩よりもかなり 大きい。

静水圧の除荷に伴う透水係数の増加（回復）は, 第 1 ステージ でわずかにみられるが, 第 2 , 第 3 ステージではほとんど認めら れない。その結果，同一圧力下の透水係数の值を比べると，除荷
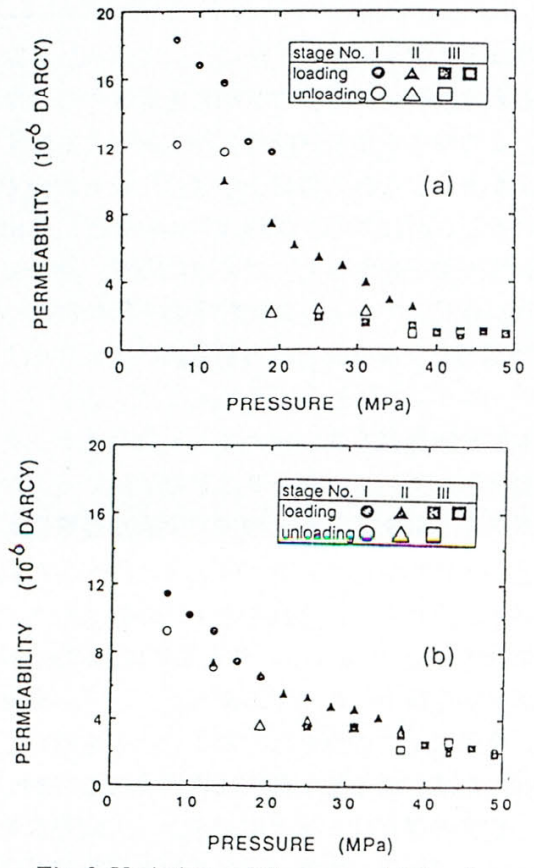

Fig. 3 Variations of the permeability of Shirahama sandstone (a) and Kimachi sandstone (b) during pressure cycles.

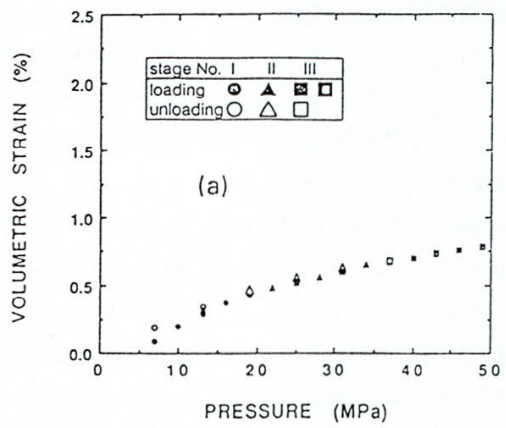

Table 2a Hysteresis of volumetric strain, permeability and velocity of Shirahama sandstone.

\section{Items}

$7 \mathrm{MPa}$ (stage I) $19 \mathrm{MPa}$ (stage II) $37 \mathrm{MPa}$ (stage III)

\begin{tabular}{lcccl}
\hline Volumetric strain & $(\%)$ & 0.11 & 0.03 & 0.02 \\
Permeability & $(\%)$ & 33.7 & 28.5 & 2.7 \\
Compressional velocity & $(\%)$ & 3.6 & 2.6 & 1.2 \\
Shear velocity & $(\%)$ & 2.6 & 2.1 & 1.0 \\
\hline
\end{tabular}

Table $2 \mathrm{~b}$ Hysteresis of volumetric strain, permeability and velocity of Kimachi sandstone.

Items

$7 \mathrm{MPa}$ (stage I) $19 \mathrm{MPa}$ (stage II) $37 \mathrm{MPa}$ (stage III)

\begin{tabular}{lcccl} 
Volumetric strain & $(\%)$ & \multicolumn{1}{c}{-} & 0.31 & 0.94 \\
Permeability & $(\%)$ & 19.6 & 26.1 & 7.6 \\
Compressional velocity & $(\%)$ & 2.1 & 1.9 & 0.6 \\
Shear velocity & $(\%)$ & 1.5 & 1.8 & 1.3 \\
\hline
\end{tabular}

*: Hysteresis is defined as the difference between values during loading and unloading.

時の方が載荷時より常に小さい。これらの挙動は両岩種に共通し て認められる。ただし，第 1 ステージにおける除荷過程での透水 係数の回復の程度については, 来待砂岩の方が白浜砂岩に比べて 少し大きい。

次に，静水王の載荷一除荷に伴う透水係数のヒステリシスを 比較すると, Table 2 に示すように, 白浜砂岩の場合はステージ が進むにつれて小さくなっており，第 3 ステージではほとんど認 められない。これに対して，来待砂岩の場合，第 2 ステージの值 が他のステージの值に比べて大きいという特徵がみられるものの， 全体としてヒステリシスは白浜砂岩に比べて小さい。

\section{$3 \cdot 2$ 体積ひずみ一静水圧の関係}

Fig.4は透水試験で得られた体積ひずみー静水圧の関係を示し たものである。次に述べるように，静水圧の載荷－除荷に対する 体積ひずみの挙動に関して，両岩石ではいくつかの点で異なって いることがわかる。第 1 に，白浜砂岩の場合，静水圧が小さい間 は圧力の載荷に伴う体積ひずみの増加（縮 みを正とする) が著しいが，高圧になると 小さくなる傾向が認められる。その結果, 体積ひずみー静水王線図は全体として上に 凸の形になっている。これに対して，来待 砂岩の場合は，載荷に伴う体積ひずみの増 加は, 静水王の低い領域よりも高い領域の 方が大きい。その結果, 体積ひずみー静水 王線図は下に凸になっている。なお，体積 ひすずみの量は, 白浜砂岩の方が来待砂岩に 比べてずっと小さい。

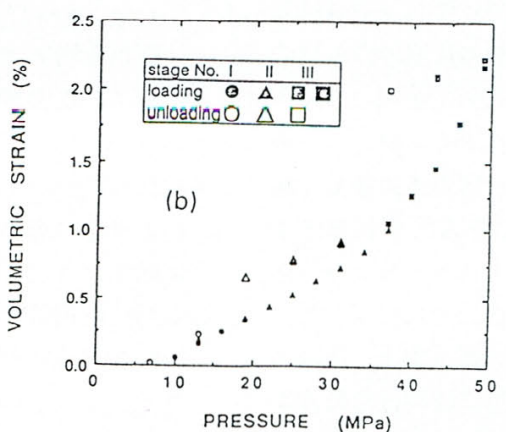

Fig. 4 Volumetric strain response of Shirahama sandstone (a) and Kimachi sandstone (b) during pressure cycles.
第 2 に, Table 2 に示すように, 静水圧 せる間のヒステリシスは，体積ひずみの方 が透水係数よりもはるかに小さいことが注 目される。また，この体積びずみのヒステ リシスは, 白浜砂岩の場合には, 静水王の 小さい第 1 ステージでは大きいが，以降は 第 2 ，第 3 ステージの順に小さくなる。特 に，第 3 ステージではほとんどヒステリシ スがみられなくなる。これに対して，来待 砂岩の場合, 体積ひずみのヒステリシスは 第 1 ステージで最も小さく，第 2 , 第 3 ス を三つのステージでそれぞれ載荷－除荷さ 

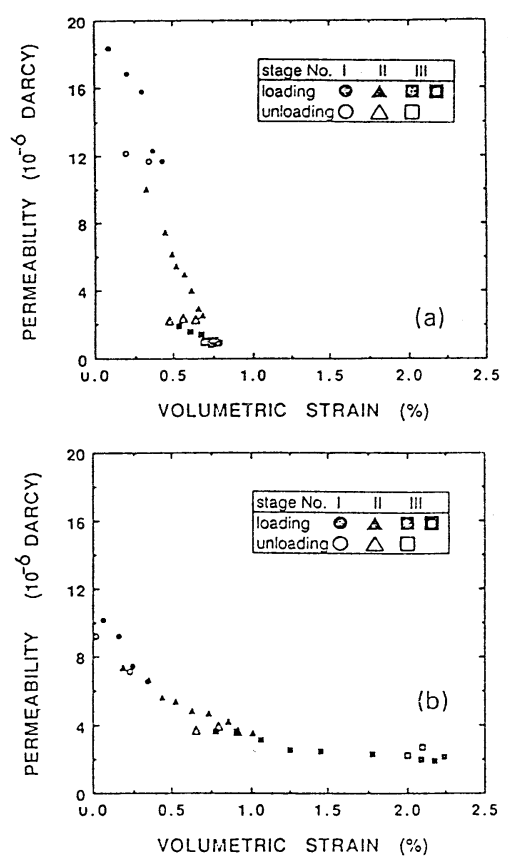

Fig. 5 Relation between permeability and volumetric strain of Shirahama sandstone (a) and Kimachi sandstone (b)
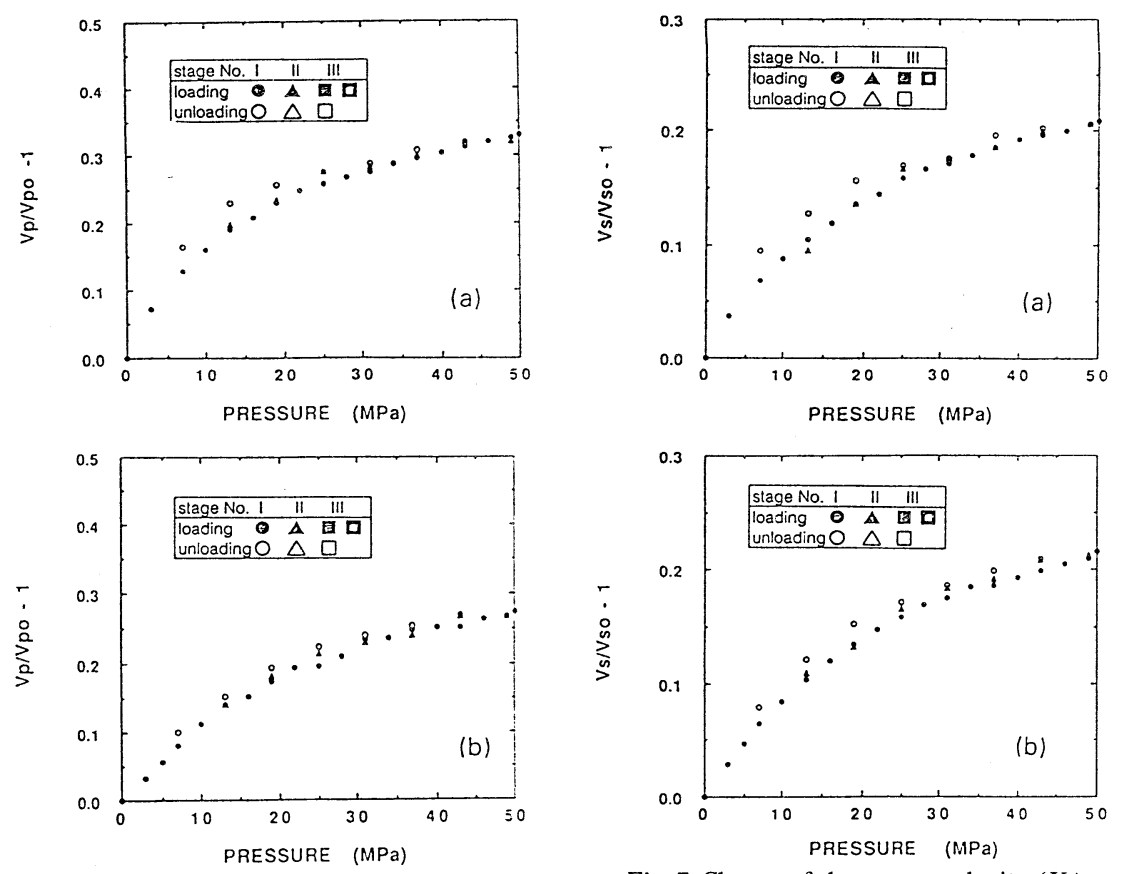

Fig. 6 Change of compressional wave velocity $\left(V_{p}\right)$ of Shirahama sandstone

(a) and Kimachi sandstone (b) during pressure cycles $\left(V_{p_{0}}\right)$ is velocity at atomospheric pressure)

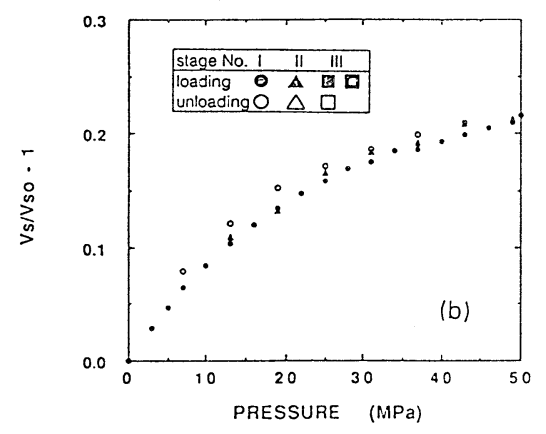

Fig. 7 Change of shear wave velocity $\left(V_{S}\right)$ of Shirahama sandstone (a) and Kimachi sandstone (b) during pressure cycles $\left(V_{S_{0}}\right)$ is velocity at atomospheric pressure).
テージの順に大きくなっている。全体として, ヒステリシスは透 水係数の場合とは逆に, 白浜砂岩の方が来待砂岩よりずっと小さ w。

\section{$3 \cdot 3$ 透水係数一体積ひずみの関係}

透水係数と体積ひずみの関係を示したのがFig.5である。両岩 種とも，第 1 , 第 2 ステージでは体積ひずみの増加に伴う透水係 数の減少が著しく, 第 3 ステージでは小さい。その結果, 透水係 数一体積ひずみ線図は右下がりの傾向を示している。しかし, 体 積ひずみの増加に伴う透水倸数の減少の程度については, 両岩種 で大きな差異があり, 透水係数一体積ひず゙み線図の傾きは, 白浜 砂岩に比べて，来待砂岩の方がずっと緩やかである。

\section{$3 \cdot 4$ 弾性波速度に及ぼす静水圧の影㖉}

Fig.6，7に示すように, 両岩種とも P 波およびS 波の速度は 静水圧の増加に伴。て増加しているが, 増加の程度は圧力が増す につれて次第に小さくなっている。なお, 両岩種とも $\mathrm{S}$ 波速度に は振動方向の差による大きな違いがないことがわかった。

$\mathrm{P}$ 波速度については, 詳細にみると次のような差異が認められ る。静水王が $19 \mathrm{MPa}$ (第 2 ステージ) と $49 \mathrm{MPa}$ (第 3 ステージ) に達したときに, 白浜砂岩の弾性波速度は, 大気圧下の速度に比 べて, それぞれ $23.0 \%, 32.5 \%$ 增加しているのに対し, 来待砂岩

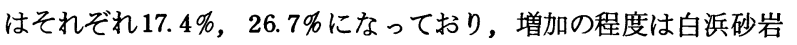
に比べて約 $6 \%$ 程度少ない。

$\mathrm{P}$ 波および $\mathrm{S}$ 波の速度は, 透水俰数や体積ひずみと異なり，静 水圧の除荷時の値の方が載荷時よりも大きい。静水圧の載荷一除 荷によるP波速度のヒステリシスについては, Table 2 に示すよ うに, 白浜砂岩の場合, 第 1 ステージで一番大きく, ステージが 進むにつれヒステリシスが徐々に減少している。これに対して, 来待砂岩の場合は, 第 2 ステージでやや大きいが, 第 1 , 第 3 ス テージでは極めて小さい。 $\mathrm{S}$ 波速度の場合にもほぼ同様な傾向が 認められる。

\section{$3 \cdot 5$ 薄片を用いた岩石の微視的構造の観察}

偏光顕徽鏡下で両岩石の鉱物組成を調べた結果をTab le 3 に
Table 3 Description of studied sandstones.

\begin{tabular}{lcc}
\hline Sandstone & Avg. radius of grains & Modal analysis \\
\hline Shirahama & $0.12 \mathrm{~mm}$ & $70 \%$ quartz \\
& & $14 \%$ feldspar \\
& & $10 \%$ clay \\
& & $6 \%$ carbonite \\
Kimachi & $0.76 \mathrm{~mm}$ & $65 \%$ clastics \\
& & $12 \%$ quartz \\
& $10 \%$ feldspar \\
& $9 \%$ zeolite \\
& $4 \%$ carbonite \\
\hline
\end{tabular}

示す。表中の数值 (\%) はポイントカウント法によって求めた各鉱 物粒子の数の全体に占める割合である。白浜砂岩を構成する主な 鉱物は石英と長石で, この他に少量の炭酸塩と粘土鉱物 (主にイ ライトとクロライト) がある。これらの粒子の径は比較的均一で, 全体に丸みを帯びている。これに対し，来待砂岩の場合は，火山 岩片から変質した凝灰質の粒子を主とし，この他に石英，沸石お よび少量の炭酸塩鉱物が存在している。鉱物粒子の平均粒径につ いては, Table 3 に示すように, 来待砂岩の方が白浜砂岩よりもず っと大きい。

Fig. 8〜11に示す偏光䫓微鏡写真において, ポアやクラック は青色樹脂によって着色されている。Fig.8は来待砂岩に多く含 まれている典型的なポフの一例を示したもので，大きな面積をも つと同時に，円形に近い形状を呈している。Fig.9にはポアが網 状につながっている様子が認められ, それらの中にはアスペクト 比の小さいものが含まれている。しかし, 全体としては, Fig. 8 に示すような大きいポアが空隙率に寄与する割合が大きい。浸透 した着色樹脂により, 複雑なポアの形だけでなく, ポアを囲む二 次鉱物と思われる沸石の結晶の様子まで鮮明に識別することがで きる。これらの沸石の結晶の存在は, ポア周辺がかって間隙水の 通路であったことを示唆している。また，ポフを取り囲む沸石は， Fig. 9 に示すように, 静水圧 $49 \mathrm{MPa}$ まで載荷した後でも破壊し ておらず，強固であることがわかる。 


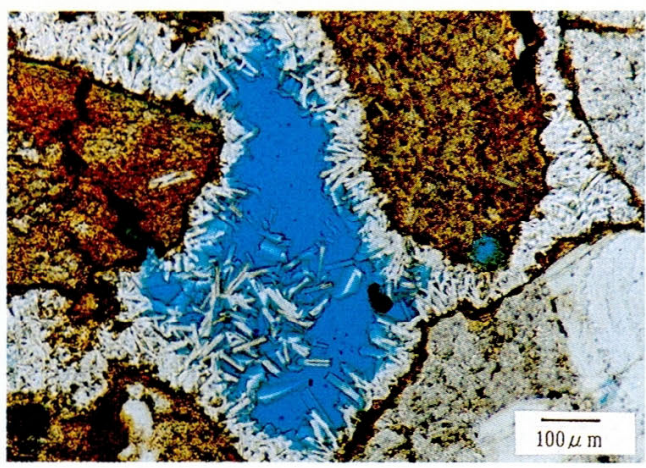

Fig. 8 Typical pore in intact Kimachi sandstone (after Xue et al. ${ }^{22}$ )) The pore is surrounded with secondary crystallized zeolite. The impregnated blue-dye-epoxy shows the pore with complex geometry.

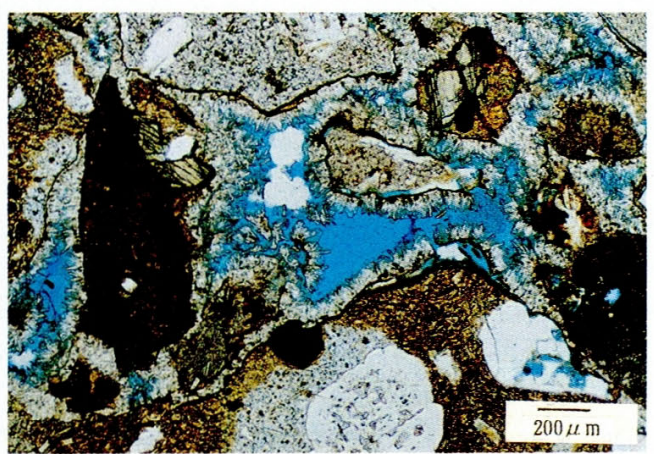

Fig. 9 Optical photomicrograph of Kimachi sandstone after stressed to $49 \mathrm{MPa}$. There is no visible evidence of pore closure.
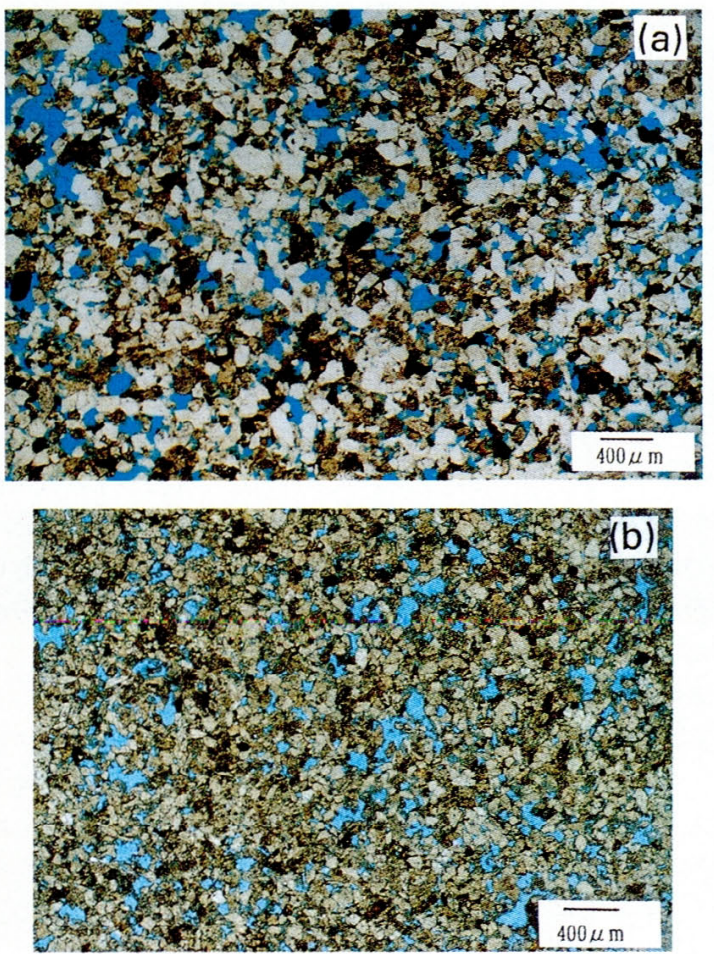

Fig. 10 Optical photomicrograph of Shirahama sandstone.

There is a visible evidence of small pore closure after the sample was stressed to $49 \mathrm{MPa}$.

(a: unstressed sample b: stressed to $49 \mathrm{MPa}$ )

粒径の小さい白浜砂岩では, Fig.10 に示すように個々のポア の面積が来待砂岩に比べて小さい。多くのポアが鉱物粒子どうし の境界に分布しており，形状もまちまちである。

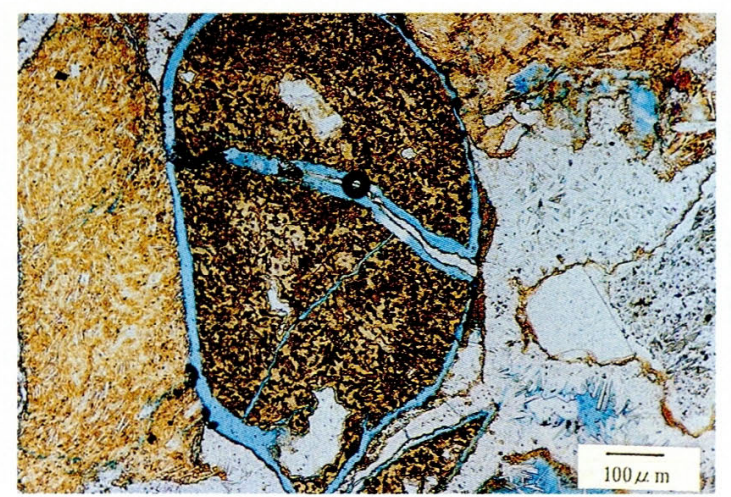

Fig. 11 Optical photomicrograph of a clastic plastically deformed after stressed to $49 \mathrm{MPa}$ in Kimachi sandstone. The impregnated blue-dye-epoxy indicates the unrecoverable deformation of the grain.
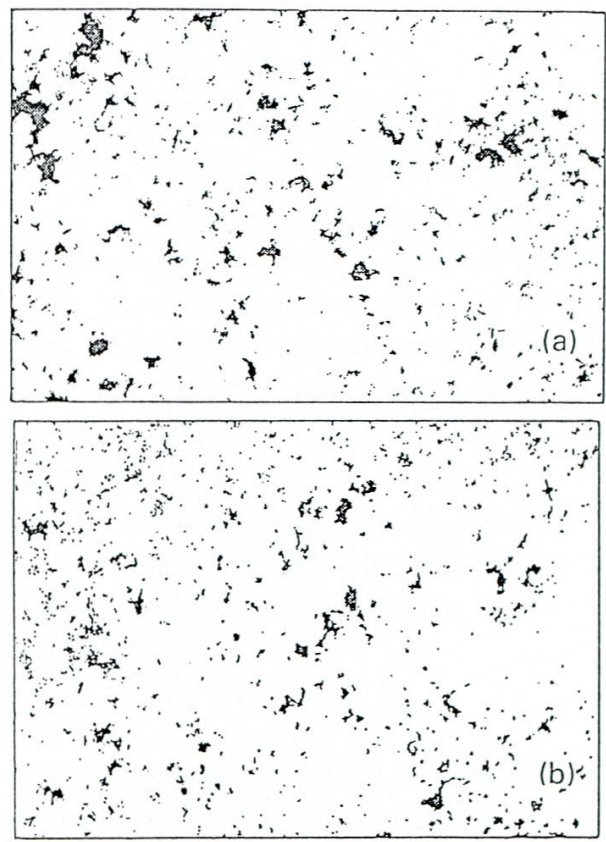

Fig. 12 Binary images of Fig. 10. The black areas are the porous zones, while the white areas are the grains. Each scene is a $328 \times 480$ array of $10 \mu \mathrm{m}$ wide pixels.

静水圧の負荷に伴う微視的構造の变化をみてみよう。来待砂岩 については，偏光影微鏡下で, $21 \mathrm{~mm}^{2}$ に存在する大きな粒子につ いて, 最も短い径の寸法 (平均 $0.037 \mathrm{~mm}$ ) を測定したところ, 静 水王の負荷に伴い平均で約 $0.5 \mu \mathrm{m}$ ほど縮んだことが明らかになっ た。火山岩片から変質した粒子は剛性が小さいため, 静水压によ って非可逆的に王縮されたことを示している。Fig.11はその一例 で, 静水圧下で起こった一様な縮みが除荷時に戻らないために, 粒子の周囲にほぼ一定の幅の空隙が発生している。なお，粒子の 縮みはひずみに換算すると約 $1 \%$ \%ある。今回は試験終了後の残 留体積ひずみを測定していないが，1 サイクルだけ負荷したとき の値は $2 \cdot 2$ で述べたように $0.7 \%$ であった。今回は 3 サイクルの 段階的な負荷をしており，この值を下回らない残留体積ひずみが 生じたと考えられる。粒子の縮みと巨視的なびずみはオーダ的に 一致しているといえよう。

白浜砂岩の場合, 顕徽鏡写真で確認できたように, ポアの分布 がランダムであり，負荷前後のポアの変化を定量的に評価する ために画像処理を行った。すなわち，偏光顕徽鏡下で得た写真を 最高解像度 $400 \mathrm{DP}$ I, 読み取り諧調 8 ビット/画素, 有効画素 


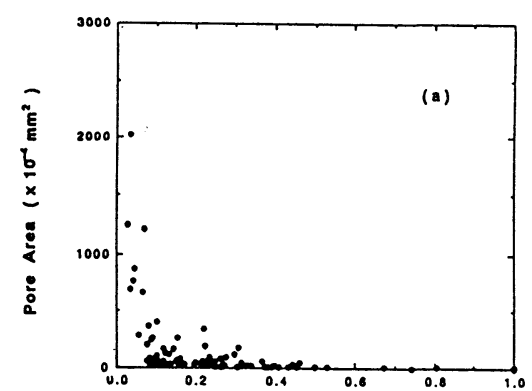

Aspect Ratlo

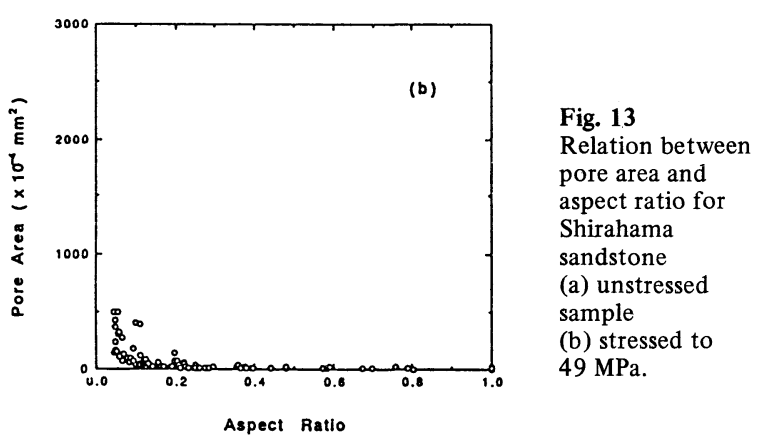

$1712 \times 2320$ ドットのカラーイメージスキャナでコンピュータに 取り込み，ポアのみを抽出してから分析に供した。Fig.12はこの ような方法で得た負荷前後のポアの様子を示している。ポアの総 面積が全体に占める割合は, 試験前が $6.54 \%$, 試験後は $4.86 \%$ と なり, 静水圧の負荷によってポアの量が明らかに減少したことを 示した。Fig.13 はポアを同じ面積を有する棈円で近似し, それ らの棈円のアスペクト比 (棈円の短軸と長軸の比) と面積の関係を 示している。無負荷状態下の面積が大きくかつアスペクト比の小 さいポアの多くは, 静水圧の負荷により閉鎖していることがわか る。

\section{4. 考 察}

ここでは，䫒微鏡による薄片の観察結果を基に，前章で得られ た透水係数, 体積ひずみ, 弾性波速度の挙動と微視的構造との関 連性について考察してみよう。

\section{$4 \cdot 1$ 透水係数の挙動と微視的構造について}

Fig.8〜11に示したように, 岩石にはさまざまな形状や寸法の ポアが存在している。この内で互いに連結し間隙水の通路を構成 しているポアやクラックのみが透水性を支配している。

Mavko and Nur ${ }^{23)}$ によると, 独立している非偏平棈円形のク ラックの閉鎖に必要な静水压の大きさ $\left(P_{c}\right)$ はクラックのアスペ クト比 $(\boldsymbol{\alpha})$ に比例する。

$$
P_{c}=\frac{3 E \alpha}{4\left(1-\nu^{2}\right)}
$$

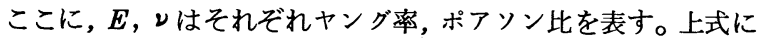
示されるように, 静水圧が比較的小さい間はアスペクト比の小さ いポアが優先的に閉鎖することになる。この式を用いると，静水 王 $49 \mathrm{MPa}$ で閉鎖するポアのアスペクト比は, $0.6 \times 10^{-2}$ (白浜砂 岩 ), $0.1 \times 10^{-1}$ (来待砂岩) と評価される。

白浜砂岩については,この現象が直接確認されており, Fig.13 に示すように静水压 $49 \mathrm{MPa}$ を負荷した後では $0.4 \times 10^{-1}$ 以下の アスペクト比のものは閉鎖している。同図は, アスペクト比の小 さいポアは，静水压の下で一度閉鎖すると除荷しても再び開口し にくいことを示している。さらに, Fig.13(a)に示すように, アス ペクト比の小さいポアは面積が大きいものが多い。従って, これ らのポアが主要な透水経路として機能する場合, 静水王によって
閉鎖すると，透水係数の急激な減少がもたらされるであろう。第 1 ステージにおいては, 静水圧の載荷時に透水係数が急激に減少 し，また，静水圧を除荷しても，透水係数はほとんど回復せずに， 結果的に大きなヒステリシスを生じている。これらの現象は上記 のポアの挙動によって説明することが可能である。

来待砂岩に関しても, 第 1 ステージでは静水圧の載荷に伴い透 水係数が著しく減少し, 除荷しても透水係数の回復が小さい。従 って, この現象については, 白浜砂岩と同じメカニズムが働いて いると考えられる。しかし, 白浜砂岩に比べるとヒステリシスが 相対的に小さいのは, アスペクト比の小さいポアの割合が少ない ためであろう。

第 2 , 第 3 ステージに進み, 静水匛のレベルが高くなるにつれ て, 両岩種とも静水圧の増加に対する透水係数の減少する割合が 次第に小さくなる。微視的構造との関連でいえば, 白浜砂岩の場 合, 静水圧が高くなるにつれ, より大きいアスペクト比のポアや クラックが閉鎖するが, これらの総面積はFig.13からわかるよう に次第に小さくなっているので，透水係数に対する寄与も小さく なる。来待砂岩についても同様な説明が可能であろう。

白浜砂岩, 来待砂岩のいずれも, 静水圧が $37 \mathrm{MPa}$ 以上の第 3 ステージにおいては, 静水匠の増加に伴い, 透水係数が減少する 傾向は依然として認められるものの, 第 1 , 第 2 ステージに比べ ると, 減少する割合は極めて小さく, また, ヒステリシスについ ても同様である。この場合には, アスペクト比の大きいポフだけ が透水経路に関与しており, 静水圧の変化に対して, 閉鎖する現 象はほとんど起こっていないことを示唆している。

\section{4・2 体積ひずみの挙動と微視的構造の関連性について}

体積ひずみは静水圧の除荷時の方が載荷時よりも常に大きく, 静水圧の載荷に伴い非可逆的な圧縮が生じることを示している。 このような体積ひずみの挙動に対しては, 透水係数とは異なり, 空 隙と岩石粒子部分から構成される岩石の微視的構造のすべてが関 与している。すなわち, 空隙については, 透水経路を構成している ポアやクラックはもちろんのこと, 独立したポアも体積ひずみに 寄与する。また, 岩石を構成している鉱物粒子自体の変形および 粒子間の相対的な変位 (再配列) も体積びずみに変化をもたらす。 ポアの閉鎖は見かけの魝性を高める作用をする ${ }^{24)}$ 。静水殴の増 加に伴い, アスペクト比の小さなポアの順に閉鎖していけば，静 水王一体積ひずみ線図は上に凸となる。白浜砂岩の場合は, Fig. 4 (a)に示すように，この予測と同じ静水王一体積ひずみ線図が得 られている。ただし，ヒステリシスは透水係数に比べて極めて小 さい。これは体積ひずみに対するポアの寄与が相対的に小さいこ とを示唆している。つまり，体積ひずみには岩石の固体部分の変 形がポアの変形以上に関与しているのであろう。

来待砂岩の場合, 静水圧一体積ひずみ線図は下に凸となってい る。また, 静水圧の增加に伴って体積びずみのヒステリシスは増 加する傾向をみせており，特に, $37 \mathrm{MPa}$ 付近では約 $1 \%$ に達する 最大のヒステリシスが生じていることが注目される。これらは来 待砂岩に多く存在する火山岩片から変質した凝灰質の粒子が軟ら かく, 静水压 $37 \mathrm{MPa}$ 付近で降伏すると考えれば説明しうる。こ れらの粒子が静水圧下で非可逆的な変形 (縮み) を起こすことは, Fig.11 で示したように顕微鏡観察で直接確認されている。来待 砂岩の体積ひずみの挙動に関しては，これらの粒子の変形の寄与 が大きいと考えられる。このような現象は, BatzleとSimmons ${ }^{25}$ が行った地熱地域の岩石を用いた研究でも認められている。上述 した凝灰質の粒子の変形挙動は, 当然のことながら透水挙動にも 影響を及ぼすであろう。来待砂岩の透水係数のヒステリシスが第 2 ステージで最大となっているのはこれと密接な関係があるもの 
と考えられる。

\section{$4 \cdot 3$ 弾性波速度と微視的構造の関連性について}

アスペクト比の小さいポアやクラックは, アスペクト比の大き いものよりも弾性波速度に著しく影響する ${ }^{26)}$ 。白浜砂岩の場合, 第 1 ステージ（ $7 \mathrm{MPa} ）$ における弾性波速度の七ステリシスは第 3 ステージの約 3 倍になっているが, これはアスペクト比の小さ いポアやクラックの閉鎖によって説明される。一方, 来待砂岩の 場合，弾性波速度のヒステリシスは白浜砂岩よりも概して小さい。 これは，4·1で述べたように, アスペクト比の小さいポアやクラ ックの閉鎖が少ないことを反映していると考えられる。

来待砂岩の場合, 静水圧 $37 \mathrm{MPa}$ のとき, 体積ひずみが大きな ヒステリシスを示しているのに対し，弾性波速度には大きなとス テリシスが認められない。個々の鉱物粒子で起こる塑性変形は弾 性波速度には強い影響をもたらさないのであろう。

\section{$4 \cdot 4$ まとめ}

白浜砂岩と来待砂岩に関し, 静水圧の載荷と除荷に伴う透水俰 数, 体積ひずみ, 弾性波速度の挙動を岩石の微視的構造と関連さ せる試みをした。白浜砂岩の場合は，石英粒子が卓越し，その境 界を埋める形で存在するポアの大きさが相対的に小さいことを反 映し, 静水王の載荷によりアスペクト比の小さいポアから起こる 非可逆的な閉鎖がヒステリシスを含む諸現象の背景になっている。 来待砂岩の場合, 軟らかい凝灰質の粒子が多く, また, 主要なポ アが円形に近いことから，静水圧が大きくなって起こる粒子の塑 性変形や粒子の再配列がヒステリシスを含む諸現象に大きく関与 している。

なお,アスペクト比の小さいポアは, 静水圧の載荷で閉鎖する と, 除荷しても再び開口しないことが, 白浜砂岩では確認され, 来待砂岩では推定された。これが他の岩種でも起こることの可否, および発生のメカニズムなどに関する検討は今後に残された課題 である。

\section{5. 結}

白浜砂岩と来待砂岩について, 静水王の載荷一除荷に伴う透水 ・変形特性を調べた。試験した静水王の範囲内で認められた白浜 砂岩と来待砂岩の透水・变形特性における差異は, 岩石内部のポ アやクラックおよび構成粒子の特性を反映している。得られた主 な結果は次の通りである。

（1）静水圧の増加とともに，体積ひずみ（縮みを十に取る）や 弾性波速度は増加し, 透水係数は減少する。

（2）静水王の載荷 一除荷に伴い, 透水係数, 体積ひずみ, 弾性 波速度にはヒステリシスが生じる。体積ひずみのヒステリシスは 空隙率の高い来待砂岩の方が空腺率の低い白浜砂岩よりも大きい。 しかし，弾性波速度や透水係数のヒステリシスに関しては，むし ろ白浜砂岩の方が大きい。この現象は静水压が比較的低い第 1 ス テージで著しい。

（3）来待砂岩の場合, 第 1 ステージでのみ, 静水圧の除荷に伴 う透水係数の回復が認められるが，さらに高い静水圧下では白浜 砂岩と同様に, 静水圧の除荷に伴う透水係数の変化がほとんど生 じない。弾性波速度は除荷過程の方が載荷過程よりも大きく, 透 水係数は逆に小さくなっている。

（4）青色顔料を添加した樹脂をポアやクラックに充填した薄片 を用い，偏光顕微鏡下で岩石の微視的構造を明膫に観察すること ができた。

(5) 白浜砂岩の場合, アスペクト比の小さいポアは全体に占め る割合が大きく, 静水圧の下で非可逆的に閉じる。来待砂岩の場 合は,アスペクト比の大きいポアが空隙率に占める割合が大きく，
静水圧下では, 変質した火山岩片が非可逆的に圧縮される。

（6）（2），(3)の諸現象は，(5)で述べた両岩石の静水圧下で起こる 王縮のメカニズムの差異によって説明しうる。つまり，ヒステリ シスの主因として, 白浜砂岩の場合には, ポアやクラックの閉鎖 を，来待砂岩の場合には，鉱物粒子の非可逆的な変形および再配 列を挙げることができる。

謝辞本研究の遂行にあたり, 地質調査所西澤 修氏(地殼 熱部)，楠瀬勤一郎氏 (環境地質部), 桑原保人氏 (地殼物理部), ならびに北海道大学中村 章助手にご指導やご䩿撻を頂いた。ま た，薄片の作製に関しては地質調査所地質標本館の大和田 朗氏 にご協力を頂いた。ここに記して感謝の意を表す。

\section{参 考 文 献}

1) Walsh, J. B. and Brace, W. F. : J. Geophys. Res., $89,9425 \sim 9431,(1984$ )

2) Zoback, M. D. and Byerlee, J. D. : J. Geophys. Res., $80,752 \sim 755$, (1975)

3) Walsh, J. B.: Int. J. Rock Mech. Min. Sci.\& Geomech. Abstr., 18, 429 435, (1981)

4) Bernabe, Y.: Mech. of Materials, [5], 235 249, (1986)

5) Koplik, J., Lin, C. and Vermette, M. : J. Appl. Phys., $56[11], 3127 \sim 3131,(1984)$

6) Doyen, P. M. : J. Geophys. Res., 93, 7729 7740, (1988)

7) Caruso, L., Simmons, G. and Wilkens, R.: Int. J. Rock Mech Min. Sci. \& Geomech. Abstr., 22, 381 392, (1985)

8) Brace, W. F.: Int. J. Rock Mech. Min. Sci.\& Geomech. Abstr., 17, 241 251, (1980)

9) Bernabe, Y., Brace, W. F. and Evans, B. : Mech. Materials, [1], 173 183, (1982)

10) Kranz, R. L., Frankel, A.D., Engelder, T. and Scholz, C.H.: Int. J. Rock Mech. Min. Sci. \& Geomech. Abstr., 16, 225 234, (1979)

11) 薛自求・石島洋二・高橋 学: 第 8 回岩の力学国内シンポジウム講 演論文集, 393 398, (1990)

12) Sprunt, E. and Brace,W. F.: Proc. 3rd Cong. ISRM, I IA , 524 529, Denver, CO (1974)

13) Feves, M. and Simmons, G.: Bull. Seism. Soc. AM, $66,1755 \sim 1765,(1976)$

14) Zoback, M.D. and Byerlee, J. D.: Am. Asso. Petrol. Geol o. Bu11., 59, 154 158, (1975)

15) Brace, W. F., Walsh, J. B. and Frangos, W. T. : J. Geophys. Res., $73[6], 2225 \sim 2236,(1968)$

16）高橋 学・薛自求: 地質 $=\approx-$, $[421], 46 \sim 54,(1989)$

17) Pittman, E. D. and Duschatko, R. W. : J. Sed. Petrol. $40[4], 1153 \sim 1157,(1984)$

18) Cheng, H. C. and Toksoz, M. N. : J. Geophys. Res., $84,7533 \sim 7542,(1979)$

19) Ehrl ich, R., Kennedy, S., Crabtree, S. J. and Cannon, R. L. : J. Sed. Petrol., 54, 1365 1378, (1984)

20) Soeder, D. J. : Am. Asso. Petrol. Geologists Bull., 74. 30 40, (1990)

21）阿部正治：地質 $=ニ-ス ，[404], 60,(1988)$

22）薛自求 ·大和田 朗 - 高橋 学・楠瀬勤一郎-石島洋二: 地質 $==$ - , [439], 50 53, (1991)

23) Mavko, G. M. and Nur, A.: J. Geophys. Res., 83, 4459 4468, (1978)

24) Schatz, J. F. : ASME Appl. Mech. Div., 16, 141 $170,(1976)$

25) Batzle, M. L. and Simmons, G. : Earth Planet. Sci. Let t. 30, 71 93, (1976)

26) Anderson, D. L., Minster, B. and Cole, D. : J. Geophys. Res., 79, 4011 4015, (1974) 